\title{
The Economic Determinants of Post-Soviet Belarus: The Role of FDI in Economic Development
}

\author{
Hong Zhong Fan ${ }^{1}$, Tatsiana Dziavochka ${ }^{1}$, Mathious Willie ${ }^{1} \&$ Mirza Nouman Ali $^{1}$ \\ ${ }^{1}$ School of Economics, Huazhong Unversity of Science and Technology, Wuhan, China \\ Correspondence: Tatsiana Dziavochka, School of Economics, Huazhong Unversity of Science and Technology, \\ Wuhan, China. Tel: 86-185-0254-9347. E-mail: tanya_devochka@mail.ru
}

Received: November 18, 2018

Accepted: December 25, 2018 Online Published: January 10, 2018

doi:10.5539/ijef.v11n2p56

URL: https://doi.org/10.5539/ijef.v11n2p56

\begin{abstract}
Adding to the vast literature readings, this study investigates the role of major determinants of economic development in Belarus from the period of 1992-2017. We employed the simple OLS regression and ARDL Bound testing approach to determine the economic indicators of Belarus. Our findings exhibit that imports and exports have been remained as major determinant whereas, FDI has not been a significant part since last three decades. Belonging to the pool of developing world, FDI has not been a determinant in Belarus while its main emphasis is on exports and imports. This study also implicates the Belarus' initiative with other developing countries to increase FDI and reduce State-owned Influence. While ensuring the differences with other economies, government must attract the economically suitable FDI avoiding any possible negative effects of FDI on GDP.
\end{abstract}

Keywords: foreign direct investment, gross domestic product, bounds testing, BRI, cointegration

\section{Introduction}

Since the dissolution of the Soviet Union in 1991, Belarus gained its Independence and thereafter has enjoyed periods of good economic performance. This period of economic prosperity coincided with maintaining an economic model based on state planning and state-owned enterprises. According the investment policy review of the republic of Belarus 2009, "FDI inflows has traditionally been very low, discouraged by frequent policy changes and an ambiguous policy stance toward private sector development. Since late 2007, in an effort to maintain high levels of economics growth, Belarus has launched reforms to develop the private sector which currently accounts for only around 25 percent of GDP. In this context, ambiguous goals have also been set to increase FDI inflows from 2.6 percent to 15-20 percent of total investment, and to move into the top 25 countries in the World Bank's "Doing Business" rankings". Since Belarus endeavored to change its policy regarding FDI, Investment has been observed above or close to 2007 levels as shown in Figure 1, which plots Belarus' FDI-GDP ratio.

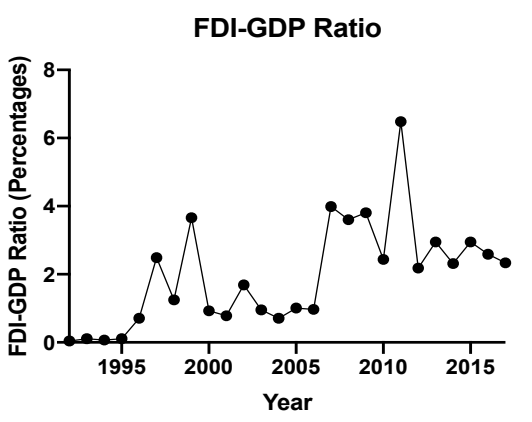

Figure 1. FDI-GDP ratio from 1992-2017

The reason for this rise is the undertaking of many FDI projects in the country. Notably, one of the largest and most promising of those projects is the China-Belarus Industrial Park (Great Stone Park). This paper will focus 
and expand a bit on this project because of the nature and magnitude of it. The authors of this paper recognize that this is not the only instance of FDI in Belarus, but it is an excellent example of FDI.

In June 2014, Belarus commenced the construction of the China-Belarus industrial park, "Great Stone". This project is one of the key undertakings in China's One Belt One Road initiative. The industrial park, which was inspired by the China-Singapore Park in Suzhou, occupies a land area of 9,150 square kilometers and is located twenty-five km away the Belarusian capital Minsk. The strategic attractiveness of the Park emanates from its immediate proximity to an international airport, railway network and the transactional motorway Berlin-Moscow. The park functions as a massive free trade area where resident companies can manufacture and assemble goods for export with little to no taxes levied. In 2014, the Belarusian president signed decree no. 326, which exempts resident companies from paying corporate taxes for the first ten years of operation. However, for the subsequent decade of operation the companies will have to pay half of the tax rates that exists within Belarus. In addition, residents will not have to pay customs duties, VAT and exercise duties for imported commodities required for manufacturing or processing. The priority business avenues for the park includes electronics, pharmaceuticals, fine chemistry, biotechnologies, mechanical engineering and new materials. This is clearly seen by the residents of the park so far which includes some of China's Biggest and most profitable multinational corporations. These include Bel Huawei, ZTE, Zoomlion Belrus, Chendu Hsinchu Silk Road Development Company, OOO Nano Pektin, YTO Technology BLR and China Merchants Commerce \& Logistics Company.

There is no doubt that the Great Stone international park serves as a catalyst for a favorable economic climate conducive for foreign direct investment. Initial estimates put investment by resident companies in the region of 1.4 - 3.7 Billion dollars from 2016-2020. The administrators of the park aim to attract more than 200 high tech companies, and employ more than 120,000 people during this time period. This ambitious project is expected to have a positive impact on the Belarusian economy. The venture will employ thousands of people, improve Belarus's trade and introduce companies to the market of the customs union and common free market zone with a population of about 170 million.

Overall, there are some positive as well as negative effects of FDI on GDP. The positive effects include Trade Effects, Human Capital Contribution, Spillover effects, Competition level and Management and Governance Practices. The negative effects of FDI include, The Crowding Out Effect, Profit Repatriation and The Dual Economy Effect.

\subsection{The Effects of FDI on the Economy (Positive and Negative)}

\section{Positive FDI Effects}

Foreign Direct Investment is believed to positively affect the receiving economy in a number of ways. According to Pelinescu (2009) there are four ways in which Foreign Direct Investment benefits the receiving economy. Firstly, Foreign Direct Investment introduces transnational companies which interact with the local economy by building production facilities and hiring workers. Secondly, the international affiliates of the transnational companies establish forward and backward linkages which stimulate production in local firms and provides a platform for the transfer of technology. Thirdly, affiliate companies can help local companies to improve their efficiency and effectiveness with competition. Finally, the entry of FDI projects can increase employment and income and have multiplier effects on the host economy. Some other positive effects are listed below.

\section{Trade Effects}

FDI tends to boost factor productivity and efficiency while increasing the productive use of resources in the home country. This leads to an increase in Capital Stock which raises output levels. The home country can then improve its trade position in the global market by increasing Exports and possibly decreasing Imports from other countries.

\section{Human Capital}

When foreign Firms migrate to other countries, they provide a range of benefits for the workers in the home country. Foreign companies provide more places of work, which intern reduces the unemployment rate. They also provide higher wages and better working conditions for employees. Most importantly, the dissemination of technology from the Firms to local employees increases effectiveness and efficiency, providing them with new and better skills.

Spillover effect

This is effect is the results of the transfer of technology from the Foreign Company to the local economy. As the name suggests. This knowledge spills over into the host economy making it more efficient. 


\section{Competition level}

As a result of the spill-over effect, local companies will have more competition from foreign firms. This will raise the level of competition in the economy and will lead to higher levels of productivity and innovation.

Management and Governance Practices

The presence of foreign Firms, through the acquisition of local firms will change the management and corporate governance of the firms. This benefits the business environment by imposing systems and processes that are more efficient and transparent.

\section{Negative FDI Effects}

The crowding out effect

As may be the result in a lot of developing countries, the presence of Foreign or Multinational Enterprises can cause emergence of monopoly power in the market. This can happen because local companies cannot match the product quality and efficiency of the MNEs or because local companies don not have access to as much resources and financing.

Profit Repatriation

This effect is self-explanatory. This happens when most or all of the profit gained by MNE is sent back to the MNE's country rather than have it circulate in the host country's economy.

The Dual Economy Effect

The Dual Economy effect occurs when there is a highly developed sector dominated by the MNEs and an underdeveloped sector dominated by the local companies. The country then depends more on the developed sector which tends to be capital intensive, while the underdeveloped sector is labor intensive. This disrupts the development of the country since most of its labor force is located in the undeveloped sector.

The Great Stone Industrial Park should have all of the aforementioned positive effects on Belarus' economy. Against this backdrop we investigate the relationship between Gross domestic product (GDP), Foreign Direct Investment (FDI), Exports , Imports, Gross capital formation (GCF), Population and Trade Openness. The purpose of this paper is to quantify the relationship between foreign direct investment and the Gross domestic product in Belarus. These results will be helpful to the Belarusian government in evaluating the benefits of the Great Stone Park. The rest of the paper is organized as follows. Section two reviews the literature. Section three analyzes the data. Section four presents the econometric methodology and results, and section five gives the conclusion.

\subsection{Literature Review}

The first observation noted is the different theoretical frameworks used by the authors in the literature. The popular framework is that of cointegration analysis, vector error correction and vector auto-regression. This type of analysis is preferred because it allows the author to investigate the backward and forward linkages between variables and, to give proper interpretation of non-stationary variables.

Rahman (2015) used the granger causality framework to investigate the relationship between FDI and GDP in Bangladesh. The data spanned 42 years from 1972-2013. The author found that there is a unidirectional relationship between FDI and GDP. It was found that GDP granger causes FDI.

Baig (2016) also uses granger causality frame work to analyze the relationship between FDI, GDP and Inflation in selected south Asian countries from 1991-2012. The author found that the relationship between FDI and GDP was not significant for countries like Pakistan, Sri Lanka and Singapore, however for Nepal the results show unidirectional positive relationship between FDI and GDP.

Hussain (2016) employs the Johansen procedure and the vector error correction framework to analyze the relationship between FDI, TRADE and Economic growth in Bangladesh from 1973-2014. The results show that FDI, TRADE and Economic Growth have a positive relationship. Other studies that used this approach includes Blin (2009), Gursoy (2013) and Antwi (2013).

Another methodology used in the literature is panel data methods. This is only used when analyzing the relationships between variables across countries.

Sandalcilar (2012) estimates a panel data model along with the Granger Causality Test based on error correction model and Holtz-Eakin, Newey and Rosen Panel Causality Test. The data used is from 1995-2011 and the countries of interest are those of the ECO region which includes Turkey, Iran and Pakistan, Azerbaijan, 
Kazakhstan, Kirghizstan, Uzbekistan, Turkmenistan, Tajikistan and Afghanistan. The results show that there is strong positive causality from FDI to GDP and a less positive causality from GDP to FDI for most of the countries.

Mehboob (2014) estimates a production function to analyze the relationships between FDI, K, L and GDP for 59 selected countries from 1992-2010. The study revealed the presence of Unidirectional causality among Gross Domestic Product and Foreign Direct Investment Inflows and Bidirectional causality between the all variables of the production Function.

Still yet another methodology used in the literature is the simple regression and Dynamic regression. The drawback this framework is that it can only be used when variables are stationary which, is rarely the case in economics. In this framework, the magnitude of the slope coefficient is emphasized as there can be no directional analysis.

Agrawal (2011) studied the relationship between Foreign Direct investment, Gross Domestic Product, Human Capital and Labour in China and India from 1993-2009. It was found that a 1\% increase in Foreign Direct Investment causes a $0.07 \%$ increase in GDP for China and a 0.02\% increase in GDP for India.

Gyedi (2013) estimates both a static and dynamic regression model to investigate the relationship between Foreign Direct Investment, Real GDP, Inflation and the Exchange Volatility Rate of Ghana from 1994-2010. In the static model, FDI and GDP have a positive relationship while in the dynamic model they have a negative relationship. The coefficients in both models were not significant which bars any real inference to be made. Other studies which employs the methodology of simple regression are Mohed (2012), Tamilselvan (2015) and Abbas (2011).

For the purpose of this study, the bounds testing approach to cointegration developed by peseran (2001) will be employed. This method is chosen because it does not need a lot of data.

Hymer (1976) propagates an interesting theory that sheds light on the literature. Hymer's theory posits that a corporation has a nationality and gives three reasons. The first reason is that a firm has a legal nationality. This provides boundaries within which the firm must operate. The second is the country of residents of the shareholders. The idea is that most shareholders may live in the same country and the firm is obligated to pay dividends in that currency. The third is the nationality of the managers, which is said to affect their loyalties. (the motivation of FDI).

Dunning (1977) introduced the OLI theory which stands for Ownership, Localization and Internalization. The theory looks at the three advantages of a Multinational corporation leading to FDI. Ownership refers to the specific knowledge capital such as managers, patents, technologies, marketing strategies etc. A company who has an abundance of this capital will be inclined to engage in FDI because the capital can be replicated in different locations without decreasing inefficiency. The advantages of localization which lead to FDI are quite attractive. They include producing close to consumers, saving transportation costs, finding cheap inputs among others. The internalization advantage deals with whether the firm contracts with the supplier in the foreign country at which time the supplier becomes an employee (Internalization) or whether it finds it best to leave the supplier separate.

Overall, there are some positive as well as negative effects of FDI on GDP. The positive effects include Trade Effects, Human Capital Contribution, Spillover effects, Competition level and Management and Governance Practices. The negative effects of FDI include, The Crowding Out Effect, Profit Repatriation and The Dual Economy Effect.

\section{Data and Methodology}

\subsection{Data Sources}

The study investigates the relationship between the log of Exports, Imports, Inward Foreign direct investment (LFDI), Population (LPOPULATION), Trade Openness (LTRADEOPENNESS), Gross Capital Formation (LGCF) and Gross Domestic Product (LGDP). The data was obtained from UNCTAD data base and the World Bank's data bank for Belarus from 1992-2017 and is measured in current US Dollars. 
GDP

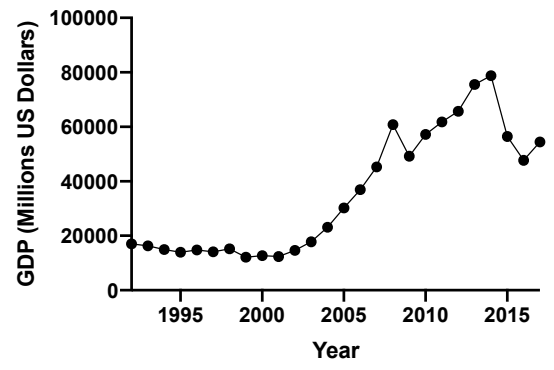

Imports

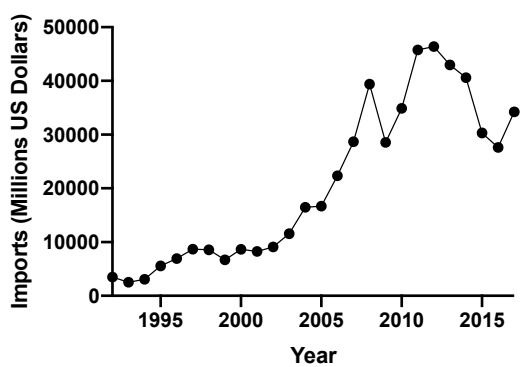

Population

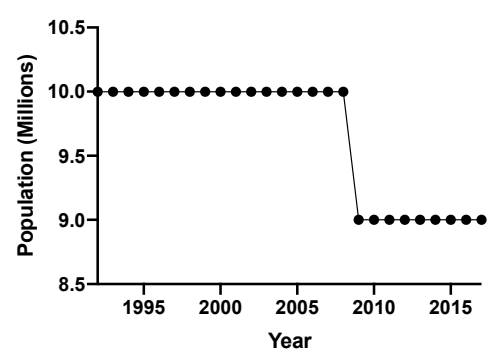

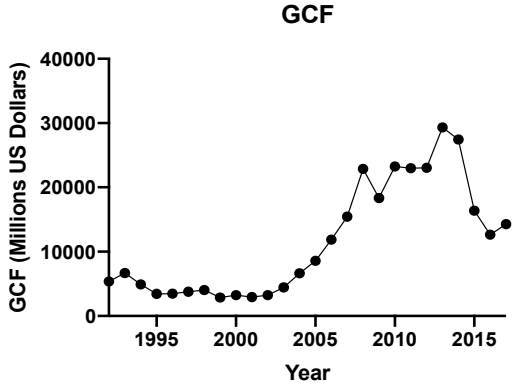

Exports

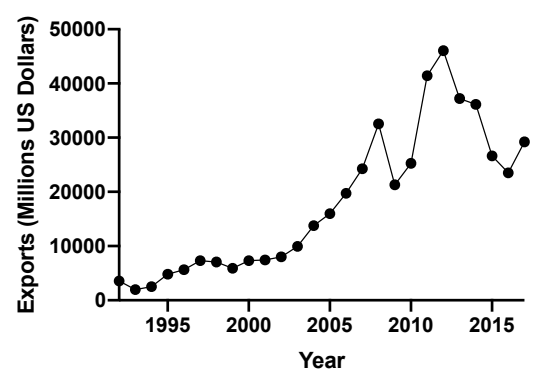

Inward FDI
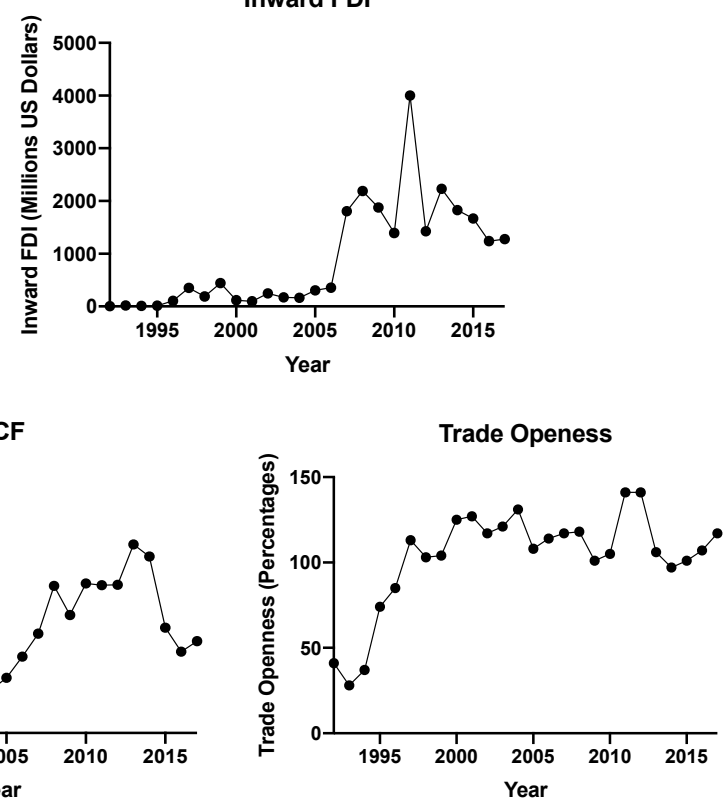

Figure 2. Plot of GDP, exports, imports, FDI, population, GCF and trade openness from 1992-2017

A careful analysis of the plotted data shows that all of the variables pretty much have an upward trend except population which has been steadily falling. It is easy to see that Belarus experienced a period of economic prosperity from around 2001 to $2012 / 2013$. This period is characterized by upward trending GDP, EXPORTS, GCF, TRADE OPENNESS. These variables will be expected to have a positive impact on GDP as their levels increase. However, during that same period, imports increased and Population decreased. Although population growth slowed consistently, the reduction in growth is not significant to restrict the growth of GDP. It can also be seen that FDI did not play a big role in the development of Belarus during the period of economic prosperity since it does not have a definite upward trend. Upon graphical inspection, the variables which are expected to positively affect GDP are the four variables which were pointed out earlier in this paragraph. Population is expected to have little to no effect while FDI's impact is inconclusive and could go either way.

Table 1. Summary statistics of level variables

\begin{tabular}{lccccccc}
\hline & GDP & Exports & Imports & FDI & K & POP & TRADEOPENNESS \\
\hline Mean & 35,353 & 17,873 & 20,695 & 905 & 11,602 & 10 & 103 \\
Median & 26,676 & 14,876 & 16,599 & 354 & 7,637 & 10 & 108 \\
Max & 78,814 & 46,060 & 46,404 & 4,002 & 29,303 & 10 & 141 \\
Min & 12,138 & 1,970 & 2,539 & 7 & 2,878 & 9 & 28 \\
Std. Dev & 22,668 & 13,278 & 14,938 & 1,005 & 8,750 & 0 & 29 \\
Skewness & 0.46 & 0.56 & 0.38 & 1.24 & 0.63 & 0.43 & -1.33 \\
Kurtosis & 1.71 & 2.09 & 1.66 & 4.31 & 1.97 & 4.17 & 1.56 \\
\hline
\end{tabular}

Note. Summary statistics for Belarus 1992-2017.The variables are summarized in Millions of US dollars. 
The summary statistics in table 1 reveal that Belarus generated an average of 35 Billion US dollars from 1992 -2017 with the maximum being 78 Billion and the minimum 12 Billion. This shows that Belarus has maintained an average level of GDP above its lowest level. Exports and imports also tell a similar story with maximums of 46 and 46.4 Billion, minimums of 1.9 and 2.5 Billion and averages of 17.9 and 20.7Billion. Like wise, since trade openness is calculated as a combination of Exports and Imports, it has also maintained an average level above its minimum with an average of $103 \%$, a maximum of $141 \%$ and a minimum of $28 \%$.

Although FDI has not been a major player in the Belarus economy, the statistics show that foreign interest was maintained. Within the period of study, FDI maintained an average of 905 Million, with a maximum of 4 Billion and a minimum of 7 Million. Next, we move to K or Gross Capital Formation. Any economist knows the importance of capital growth to a healthy economy. In Belarus' case, capital stock was maintained at an average of 11 Billion, with a maximum of 29 Billion and a minimum of 2 Billion. As a nation's population increases, and with it its labor force, one would expect that it should contribute positively to GDP growth. The descriptive statistics show that Belarus' population has also maintained an average level above its lowest value.

Table 2. Summary statistics of logged variables

\begin{tabular}{lccccccc}
\hline & LGDP & LEXPORTS & LIMPORTS & LFDI & LK & LPOPULATION & LTRADEOPENNESS \\
\hline Mean & 24.07 & 23.27 & 23.42 & 19.62 & 22.87 & 16.1 & 4.57 \\
median & 24 & 23.42 & 23.53 & 19.69 & 22.75 & 16.1 & 4.68 \\
Maximum & 25.09 & 24.55 & 24.56 & 22.11 & 24.1 & 16.1 & 4.95 \\
Minimum & 23.22 & 21.4 & 21.65 & 15.76 & 21.78 & 16.1 & 3.33 \\
Std.Dev & 0.68 & 0.91 & 0.9 & 1.82 & 0.82 & 0.03 & 0.41 \\
Skewness & 0.11 & -0.36 & -0.37 & -0.67 & 0.09 & 0.42 & -1.99 \\
Kurtosis & 1.31 & 2.03 & 1.91 & 2.45 & 1.44 & 1.54 & 5.96 \\
\hline
\end{tabular}

Note. Summary statistics for logged variables for Belarus from 1992-2017.

To obtain a better understanding of the relationship between the variables we compute the correlation matrix. As expected, it shows strong positive correlations. Special emphasis is given to the correlation between LFDI and LGDP which is 0.80 . These results are a pretext to the detailed investigation to follow. The study will go beyond this simple correlation analysis, however the expected signs on coefficients are expected to be positive except for IMPORTS.

Table 3. Correlation matrix

\begin{tabular}{lccccccc}
\hline & LGDP & LEXPORTS & LIMPORTS & LFDI & LGCF & LPOPULATION & LTRADEOPENNESS \\
\hline LGDP & 1 & 0.9 & 0.91 & 0.8 & 0.98 & -0.9 & 0.34 \\
LEXPORTS & 0.9 & 1 & 1 & 0.92 & 0.84 & -0.96 & 0.71 \\
LIMPORTS & 0.91 & 1 & 1 & 0.93 & 0.85 & -0.97 & 0.7 \\
LFDI & 0.8 & 0.92 & 0.93 & 1 & 0.74 & -0.89 & 0.72 \\
LGCF & 0.98 & 0.84 & 0.85 & 0.74 & 1 & -0.84 & 0.23 \\
LPOPULATION & -0.9 & -0.96 & -0.97 & -0.89 & -0.84 & 1 & -0.64 \\
LTRADEOPENNESS & 0.34 & 0.71 & 0.7 & 0.72 & 0.23 & -0.64 & 1 \\
\hline
\end{tabular}

Note. The correlations were calculated with the logged variables, where L stands for logged.

\section{Methodology and Results}

\subsection{Econometric Approach}

\subsubsection{OLS Estimation}

In this study we make use of two econometric procedures. The first is a simple OLS estimation of the log of the four variables where the following model is assumed:

LGDP $=\mathrm{f}$ (LFDI, LEXPORTS, LIMPORTS, LFDI, LGCF, POPULATION, LTRADEOPENNESS)

LGDP $=$ The Log of Gross Domestic Product

LFDI $=$ The Log of Foreign Direct Investment Inflows

LGCF $=$ The Log of Gross Capital Formation

LEXPORTS $=$ The Log of Exports 


\subsubsection{Autoregressive Distributed Lag Approach to Cointegration}

In this study the ARDL bounds testing procedure, developed by Pesaran et al. (2001), is adopted. This approach is preferable to other single equation techniques like the Engle and Granger et al. (1987) two step estimator; because it assumes that all variables are endogenous. Also, the ARDL approach is applicable whether the regressors are purely $\mathrm{I}(0)$, purely $\mathrm{I}(1)$ or co-integrated

We assume the same model as the OLS estimation as the general model for this procedure.

The first step of the bounds test is to estimate an unrestricted error correction version of equation (1) by OLS. The unrestricted error (equilibrium) correction model (ECM) proposed by Pesaran et al. (2001) applies the fundamental principles of the Johansen five error correction muliti-variance of which there are five possible models. The models are chosen based on the assumed components of the data. This is determined from a graphical inspection of the data. The possible models are as follows:

Case I (no intercepts; no trends)

$$
\Delta Y_{t}=\Pi Y_{t-i}+\Pi X_{t-i}+\sum_{i=1}^{p-1} \psi \Delta Z_{t-i}+\delta \Delta X_{t-i}+\mu
$$

This model is chosen if it is assumed that the data has no linear trends and no intercepts are desired.

Case II (restricted intercepts; no trends)

$$
\Delta Y_{t}=\Pi\left(Y_{t-i}-\mu\right)+\Pi\left(X_{t-i}-\mu\right)+\sum_{i=1}^{p-1} \psi \Delta Z_{t-i}+\delta \Delta X_{t-i}+\mu
$$

This model is chosen if it is assumed that the data has no linear trends and if is fit to restrict the intercepts to a certain value.

Case III (unrestricted intercepts; no trends)

$$
\Delta Y_{t}=C_{0}+\Pi Y_{t-i}+\Pi X_{t-i}+\sum_{i=1}^{p-1} \psi \Delta Z_{t-i}+\delta \Delta X_{t-i}+\mu
$$

This model is chosen if it is assumed that the data has no linear trends and the intercepts are not restricted to any values.

Case IV (unrestricted intercepts; restricted trends)

$$
\Delta Y_{t}=C_{0}+\Pi\left(Y_{t-i}-\gamma_{y} t\right)+\Pi\left(X_{t-i}-\gamma_{x} t\right)+\sum_{i=1}^{p-1} \psi \Delta Z_{t-i}+\delta \Delta X_{t-i}+\mu
$$

This model is chosen if the data is assumed to have a trend, but is it found suitable to restrict the linear trends between certain values. Also, the intercept is unrestricted.

Case V (unrestricted intercepts; unrestricted trends)

$$
\Delta Y_{t}=C_{0}+C_{1} t+\Pi Y_{t-i}+\Pi X_{t-i}+\sum_{i=1}^{p-1} \psi \Delta Z_{t-i}+\delta \Delta X_{t-i}+\mu
$$

This model is chosen if the data is assumed to have a trend and the intercept is not restricted between values. Both the linear trend and the intercept have no restrictions placed on them in this model specification.

Where $\Delta Y_{t}=$ Difference of Dependent Variable

$C_{0}=$ Constant

$C_{1} t=$ Linear Trend

$Y_{t-i}=$ lagged dependent variable

$X_{t-i}=$ lagged independent variable

$\Delta Z_{t-i}=$ error correction term

$\Delta X_{t-i}=$ lagged independent variable differenced

See pesaran et al. (2001). Since all of the variables in the study exhibit a trend, the decided model is case five. Following is the specified equation:

$$
\begin{gathered}
\Delta G D P_{t}=C_{0}+C_{1} t+\Pi G D P_{t-i}+\Pi F D I_{t-i}+\Pi E X P O R T S_{t-i}+\Pi G C F_{t-i}+\sum_{i=1}^{p-1} \psi \Delta Z_{t-i}+\delta \Delta F D I_{t-i}+ \\
\delta \Delta E X P O R T S_{t-i}+\delta \Delta G C F_{t-i}+\mu
\end{gathered}
$$

The bounds procedure for testing the relationship between two variables involves an $F$ test on the joint null hypothesis that the coefficients of level variables are jointly zero. It should be noted that the F- statistics follow a non-standard distribution. Hence, instead of the conventional critical values, the $\mathrm{F}$ test involves two asymptotic critical bounds covering all possible classifications of the variables, i.e. whether they are $\mathrm{I}(1), \mathrm{I}(0)$ or mutually co-integrated. The lower bound values assume that the variables are purely $\mathrm{I}(0)$, and the upper bound values assume that they are purely I(1). If the computed F-statistic exceeds its respective upper critical values, then 
there is evidence of a long -run relationship; if below the null of no cointegration, it cannot be rejected; and finally, if it lies between the bounds, inference is inconclusive. Once cointegration is established, the long- run and corresponding error correction models can be estimated. As a preliminary step to the empirical analysis, the order of integration of the variables is determined.

Table 4. Unit root test

\begin{tabular}{lcccc}
\hline & \multicolumn{2}{c}{ Level } & \multicolumn{2}{c}{ First Difference } \\
\cline { 2 - 5 } Variable & Stat & Prob & Stat & Prob \\
\hline LGDP & -1.57 & $(-0.77)$ & -3.53 & $(0.01)$ \\
DLIMPORTS & -1.35 & $(0.85)$ & -4.58 & $(0.00)$ \\
DLEXPORTS & -1.79 & $(0.68)$ & -5.06 & $(0.00)$ \\
DLGCF & -2.37 & $(0.38)$ & -5.61 & $(0.00)$ \\
DLINWARD FDI & -1.37 & $(0.84)$ & -3.53 & $(0.01)$ \\
DLPOPULATION & -3.65 & $(0.04)$ & - & $(-)$ \\
DTRADE OPENNESS & -5.13 & $(0.00)$ & - & $(-)$ \\
\hline
\end{tabular}

Note. Augmented Dickey Fuller Test to test for unit roots in the data at both level and first difference forms of the data.

Table 5. Order of integration

\begin{tabular}{lc}
\hline & Order of Integration \\
\hline LGDP & $\mathrm{I}(1)$ \\
DLIMPORTS & $\mathrm{I}(1)$ \\
DLEXPORTS & $\mathrm{I}(1)$ \\
DLGCF & $\mathrm{I}(1)$ \\
DLINWARD FDI & $\mathrm{I}(1)$ \\
DLPOPULATION & $\mathrm{I}(0)$ \\
DTRADE OPENNESS & $\mathrm{I}(0)$ \\
\hline
\end{tabular}

Note. I(0) signifies integrated of order 0 and I(1) signifies integrated of order 1.

This is done to ensure that none of the variables are integrated of order two I(2). The Augmented Dickey - Fuller test is used to determine the level of stationarity. The null hypothesis of this unit root test states that the series has a unit root. Failure to reject the null hypothesis means that the series is not stationary. The results in tables 4 and 5 show that none of the variables are I(2). Therefore, the ARDL approach is undertaken.

In the first stage of the ARDL analysis, it is standard procedure to ascertain the existence of a long run relationship among the variables. The maximum lag length is set at 2 since the data being used is annual data. The results shown in table 6 imply that the null of no co-integration can be rejected. Therefore, there exists a cointegrating relationship between the four variables of interest.

Table 6. Bounds test

\begin{tabular}{lccc}
\hline Test Statistic & & Value & $\mathrm{k}$ \\
\hline F-statistic & & 4491.848 & 6 \\
Critical Value Bounds & & I0 Bound & I1 Bound \\
Significance & $10 \%$ & 2.53 & 3.59 \\
& $5 \%$ & 2.87 & 4 \\
& $2.50 \%$ & 3.19 & 4.38 \\
& $1 \%$ & 3.6 & 4.9 \\
\hline
\end{tabular}

Note. Bounds Testing procedure based on a 6-parameter analysis. The F statistic is outside of the testing bounds which signifies a cointegrating relationship.

Given the existence of a co-integrating relationship, the long run conditional ARDL and the error correction models can be estimated. The Schwarz-Bayesian criterion is employed to determine the order of the ARDL. The chosen order is an ARDL $(1,1,2,0)$ model. 


\subsection{Results}

Table 7. OLS estimation

\begin{tabular}{|c|c|c|c|c|c|}
\hline \multicolumn{6}{|c|}{ Dependent Variable is DLGDP } \\
\hline \multirow{2}{*}{$\begin{array}{l}\text { Variable } \\
\text { DLIMPORTS }\end{array}$} & \multicolumn{2}{|c|}{ Coef(SE) } & \multicolumn{3}{|c|}{ Tstat(Prob) } \\
\hline & -0.25 & $(0.19)$ & & 2.61 & $(0.19)$ \\
\hline DLEXPORTS & 0.4 & $(0.15)$ & & -1.36 & $(0.02)$ \\
\hline DLGCF & 0.57 & $(0.06)$ & & 10.34 & $(0.00)$ \\
\hline DLINWARD FDI & 0 & $(0.01)$ & & 0.03 & $(0.98)$ \\
\hline LPOPULATION & -0.66 & $(0.51)$ & & -1.29 & $(0.21)$ \\
\hline LTRADE OPENNESS & -0.04 & $(0.04)$ & & -0.95 & $(0.36)$ \\
\hline $\mathrm{C}$ & 10.86 & $(8.38)$ & & 1.3 & $(0.21)$ \\
\hline R-Squared & 0.93 & & Mean Dependent Var & & 0.05 \\
\hline Adj- R-squared & 0.9 & & SD. Dependent Var & & 0.17 \\
\hline S.E. Of Regression & 0.05 & & Akaike info criterion & & -2.84 \\
\hline Sum Squared Resid & 0.05 & & Schwarz criterion & & -2.5 \\
\hline Log Likelihood & 42.48 & & Hannan-Quinn criterion & & -2.74 \\
\hline F-Statistic & 37.17 & & Durbin-Watson Stat & & 2.34 \\
\hline Prob(F-Statistic) & 0 & & & & \\
\hline
\end{tabular}

Note. Standard errors and probabilities are in parenthesis.

Table 8 . Tests for serial correlation and heteroskedasticity

\begin{tabular}{cccc}
\hline Statistic & \multicolumn{3}{c}{ Probability } \\
\hline F-Statistic & 1.12 & Prob F(2,12) & 0.3499 \\
Obs* R-Squared & 3.08 & Prob Chi-Square(2) & 0.2149 \\
\hline
\end{tabular}

Note. Breusch-Godfery Serial Correlation Test.

\begin{tabular}{cccc}
\hline Statistic & \multicolumn{3}{c}{ Probability } \\
\hline F-Statistic & 1.37 & Prob F(9, 14) & 0.2784 \\
Obs* R-Squared & 7.85 & Prob Chi-Square(9) & 0.2496 \\
Scaled Explained SS & 6.71 & Prob Chi-Square(9) & 0.3486 \\
\hline
\end{tabular}

Note. Breusch-Pagan-Godfery Test for Heteroskedasticity.

The OLS results seem to be quite counterintuitive for two of the variables. First of all, it can be clearly seen that only two of the variables are significant. These variables are DLEXPORTS and DLGCF. The signs coincide with expectations, positing that Exports and Capital Stock have a positive relationship with GDP. Indeed, a 1\% increase in exports will increase GDP by $0.40 \%$. also, a $1 \%$ increase in the Capital stock will increase GDP by $0.57 \%$. Although all of the other variables are insignificant, their signs are not as expected. The results states that Trade Openness and Population growth have negative effects on GDP. The seeming puzzling effect of Population growth is explainable since Belarus' population has been steadily declining as GDP has been rising. In order to get a deeper understanding of the relationship between the variables, the ARDL approach to cointegration is employed. The first step of the ARDL process is to estimate the ARDL model chosen by the information criteria. The chosen model is an $\operatorname{ARDL}(1,0,0,0,0,0,1)$ model. This is then dissected into two parts, a short-run analysis and a long-run analysis.

Table 9. Autoregressive distributive lag estimates

\begin{tabular}{|c|c|c|c|c|}
\hline \multicolumn{5}{|c|}{ ARDL $(1,0,0,0,0,0,1)$ Model Dependent Variable is DLGDP } \\
\hline Variable & Coef(SE) & & Tstat(Prob) & \\
\hline DLGDP (-1) & 0.01 & $(0.01)$ & 0.69 & $(0.50)$ \\
\hline DLEXPORTS & 0.44 & $(0.02)$ & 26.37 & $(0.00)$ \\
\hline DLIMPORTS & 0.57 & $(0.03)$ & 18.36 & $(0.00)$ \\
\hline DLFDI & 0.00 & $(0.00)$ & -0.04 & $(0.96)$ \\
\hline DLGCF & -0.02 & $(0.02)$ & -0.88 & $(0.39)$ \\
\hline LPOPULATION & 0.12 & $(0.22)$ & 0.55 & $(0.59)$ \\
\hline
\end{tabular}




\begin{tabular}{|c|c|c|c|c|}
\hline LTRADEOPENNESS & $(0.02)$ & & -40.03 & $(0.00)$ \\
\hline LTRADEOPENNESS $(-1)$ & $(0.03)$ & & 36.88 & $(0.00)$ \\
\hline $\mathrm{C}$ & $(3.57)$ & & -0.57 & $(0.57)$ \\
\hline TREND & $0.00 \quad(0.00)$ & & 0.48 & $(0.64)$ \\
\hline R-Squared & 0.99 & Mean Dependent Var & & 0.05 \\
\hline Adj- R-squared & 0.99 & SD. Dependent Var & & 0.17 \\
\hline S.E. Of Regression & 0.01 & Akaike info criterion & & -7.3 \\
\hline Sum Squared Resid & 0.00 & Schwarz criterion & & -6.81 \\
\hline Log Likelihood & 97.63 & Hannan-Quinn criterion & & -7.17 \\
\hline F-Statistic & 2442.40 & Durbin-Watson Stat & & 2.33 \\
\hline Prob(F-Statistic) & 0.00 & & & \\
\hline
\end{tabular}

Note. Standard errors and probabilities are in parenthesis.

Table 10. Tests for serial correlation and heteroskedasticity

\begin{tabular}{cccc}
\hline Statistic & \multicolumn{2}{c}{ Probability } \\
\hline F-Statistic & 0.889313 & Prob F(2,12) & 0.4364 \\
Obs* R-Squared & 3.09806 & Prob Chi-Square(2) & 0.2125 \\
\hline
\end{tabular}

Note. Breusch-Godfery Serial Correlation Test.

\begin{tabular}{cccc}
\hline Statistc & \multicolumn{2}{c}{ Probability } \\
\hline F-Statistic & 2.854795 & Prob F(9,14) & 0.0384 \\
Obs* R-Squared & 15.53506 & Prob Chi-Square(9) & 0.0772 \\
Scaled Explained SS & 3.976826 & Prob Chi-Square(9) & 0.9129 \\
\hline
\end{tabular}

Note. Breusch-Pagan-Godfery Test for Heteroskedasticity.

Table 11 shows the shorn-run results for the ARDL model. One thing to notice is the trend variable which is highly significant. Secondly, the coefficient of TRADEOPENNESS is negative, suggesting a negative relationship with GDP in the short-run. A $1 \%$ increase in the TRADEOPENNESS position will decrease GDP by 0.9\%. This of course is not surprising since imports are greater than exports from 1993-2017. The constant term is also significant at the $1 \%$ level, suggesting that if all the variables in the equation were zero, the value of DLGDP would be $-2.04 \%$.

Table 11. Short-run results

\begin{tabular}{crrrrr}
\hline Variable & \multicolumn{2}{c}{ Coef(SE) } & \multicolumn{2}{c}{ Tstat(Prob) } \\
\hline TREND & 0 & $(0.00)$ & 2.54 & $(0.02)$ \\
TRADEOPENNESS & -0.99 & $(0.01)$ & -132.47 & $(0.00)$ \\
COINTEQ $(-1)$ & -0.99 & $(0.00)$ & -211.94 & $(0.00)$ \\
C & -2.04 & $(0.01)$ & -207.42 & $(0.00)$ \\
\hline
\end{tabular}

Note. Standard Errors and Probabilities are in parenthesis.

Table 12. Long-run results

\begin{tabular}{lrrrr}
\hline \multicolumn{1}{c}{ Variable } & \multicolumn{2}{c}{ Coef(SE) } & \multicolumn{2}{c}{ Tstat(Prob) } \\
DLIMPORTS & 0.58 & $(0.03)$ & 17.26 & $(0.00)$ \\
DLEXPORTS & 0.45 & $(0.02)$ & 26.84 & $(0.00)$ \\
DLGCF & -0.02 & $(0.00)$ & -0.88 & $(0.40)$ \\
DLINWARD FDI & 0 & $(0.00)$ & -0.04 & $(0.97)$ \\
LPOPULATION & 0.12 & $(0.22)$ & 0.54 & $(0.60)$ \\
LTRADE OPENNESS & 0.02 & $(0.01)$ & $2.97 \quad(0.01)$ \\
\hline
\end{tabular}

Note. Standard Errors and Probabilities are in parenthesis.

Table 12 shows the long-run results of the ARDL model. The model reveals that capital stock, FDI and Population are not significant and therefore has no long-run relationship with GDP. However, the results show that a $1 \%$ increase in IMPORTS will increase GDP by $0.58 \%$. It also shows that a $1 \%$ increase in exports will increase GDP by $0.45 \%$. also, a $1 \%$ increase in the trade openness position will increase GDP by $0.02 \%$. 


\section{Conclusion}

This study employs the ARDL procedure to investigate the major determinants of Belarus' Economy. To investigate the determinants, we have observed short and long-run coefficients to see their impact on GDP for Belarus from 1992-2017.Other methodologies applied includes graphical analysis, correlation analysis and OLS. The ARDL results posit that in either short-run or long-run, FDI has no relationship with economic development whereas, trade proxies (imports and exports) are found significant evidencing the major emphasis of Belarus on trade.

Since the study is limited to one country, it may not provide the evidence on other regional countries. To further check the robustness of investment deficiency in the portfolio of Belarusian economy, it is important to consider the presence of any linkage between trade and investments of the country. Moreover, it is also important to consider economic dynamics of other states which were once a part of the Soviet Union and broke away in the early 1990's for future research and construct the comparative analysis of these countries' economies.

Based on the results of our study, the implications for Belarus is to attract the foreign direct investments especially with the consideration of Great Stone Industrial Park that may assist in strengthening the economic development of the country. According to the results, since the dissolution of the Soviet Union, the FDI driven initiative has little to no effect on GDP in Belarus. In line with its policies to increase the amount of FDI in the country, one of the implications could be reducing the influence of state-owned enterprises. Secondly, strict supervision of the projects ensuring the optimum utilization of investments efficiently for economic growth of the country is highly required. Government must also seek to attract the right type of Foreign Direct Investment to avoid any negative effects such as the Dual Economy Effect, the Profit Repatriation Effect and the Crowding out effect. Domestic Market-seeking MNEs should be avoided and Export Oriented MNEs should be welcomed.

Since Belarus' Independence, FDI has played no significant role as a major determinant of the economic development. With the results achieved, it is necessary to improve the investment friendly environment ensuring the efficient economic growth of the country.

\section{References}

Ali, R. S., \& Ali, A. (2012). Foreign Direct Investment and Gross Domestic Product: An Application on ECO Region. International Journal of Business and Social Science, 189-198.

Anonymous. (2009). The Impact of Foreign Direct Investment on the Economic Growth and Countries' Export Potential. Romanian Journal of Economic Forecasting, 153-169.

Baig, M. M., Kiran, S., \& Bilal, M. (2016). Relationship between FDI and GDP: A Case Study of South Asian Countries. Journal of Business \& Financial Affairs, 5, 199.

Faruk, G., Ahmet, S., \& Hüseyin, K. (2013). FDI and Economic Growth Relationship. International Journal of Economics and Financial Issues, 519-524.

Francis, G., Mary, O., \& Jonatha, K. E. (2013). Foreign Direct Investment and Gross Domestic Product in Ghana. International Journal of Academic Research in Accounting, Finance and Management Sciences, 256-265.

Gaurav, A., \& Mohd., A. K. (2011). Impact of FDI on GDP: A Comparative Study of China and India. International Journal of Business and Management, 71-79.

Haque, M. E. H., \& Mahfuzul. (2016). Foreign Direct Investment, Trade, and Economic Growth: An Empirical Analysis of Bangladesh. Economies, 1-14.

Ibrahim, K., \& Mohammad, M. R. (2015). Foreign Direct Investment (FDI) and Gross Domestic Product (GDP) in Bangladesh: A Cointegration Analysis. Journal of Economics and Sustainable Development, 198-208.

Kontsavenko, I. (2015). Great Stone of Tomorrow. Retrieved June 21, 2017 from http://www.belarus-economy.by/ru/annonces-ru/view/chitajte-v-nomere-58/

Mehboob, S. K., \& Farhan. (2014). Impact of FDI on GDP: An Analysis of Global Economy on Production Function. Munich Personal RePEc Archive, 1-14.

Mohd., Y., \& Izhar, A. (2015). Impact of Foreign Direct Investment on Gross Domestic Product of India Since Liberalization (pp. 1827-1834).

Ouattara, M. B., \& Bazoumana. (2009). Foreign Direct Investment and Economic Growth in Mauritius:Evidence from Bounds Test Cointegration. Économie Internationale, 47-61.

Pesaran, M. H., Shinb, A. Y., \& Richard, J. S. (2001). Bounds Testing Approaches to the Analysis of Level 
Relationships. Journal of Applied Econometrics, 289-326. https://doi.org/10.1002/jae.616

Petr, H., \& Bal-Domanska, B. (2016). Impact of Foreign Direct Investment on Economic Growth in Central European Countries. Inzinerine Ekonomika-Engineering Economics, 294-303.

Qaiser, A., Salman, A., Ali, S. N., \& Hafiz, A. (2011). Impact of Foreign Direct Investment on Gross Domestic Product. Global Journal of Management and Business Research, 34-40.

Samuel, A., \& Xicang, Z. (2013). Impact of Foreign Direct Investment and Economic Growth in Ghana: A Cointegration Analysis. International Journal of Business and Social Research, 64-74.

Tamilselvan, M., \& Manikandan, S. (2015). A Study on Impact of Foreign Direct Investment on Gross Domestic Production in India. International Journal of Academic Research in Business and Social Sciences, 224-232. https://doi.org/10.6007/IJARBSS/v5-i10/1870

\section{Copyrights}

Copyright for this article is retained by the author(s), with first publication rights granted to the journal.

This is an open-access article distributed under the terms and conditions of the Creative Commons Attribution license (http://creativecommons.org/licenses/by/4.0/). 